\title{
CLAIMS-SHIFTING: \\ THE PROBLEM OF PARALLEL REIMBURSEMENT REGIMES
}

Olesya Fomenko

Jonathan Gruber

Working Paper 22318

http://www.nber.org/papers/w22318

\author{
NATIONAL BUREAU OF ECONOMIC RESEARCH \\ 1050 Massachusetts Avenue \\ Cambridge, MA 02138 \\ June 2016
}

Gruber acknowledges funding from WCRI. We are extremely grateful to Rick Victor for his guidance throughout this project, and to John Ruser and a set of WCRI external reviewers for helpful comments. The views expressed herein are those of the authors and do not necessarily reflect the views of the National Bureau of Economic Research.

NBER working papers are circulated for discussion and comment purposes. They have not been peer-reviewed or been subject to the review by the NBER Board of Directors that accompanies official NBER publications.

(C) 2016 by Olesya Fomenko and Jonathan Gruber. All rights reserved. Short sections of text, not to exceed two paragraphs, may be quoted without explicit permission provided that full credit, including $(\odot)$ notice, is given to the source. 
Claims-Shifting: The Problem of Parallel Reimbursement Regimes

Olesya Fomenko and Jonathan Gruber

NBER Working Paper No. 22318

June 2016

JEL No. I13,I18

\begin{abstract}
$\underline{\text { ABSTRACT }}$
Parallel reimbursement regimes, under which providers have some discretion over which payer gets billed for patient treatment, are a common feature of health care markets. In the U.S., the largest such system is under Workers' Compensation (WC), where the treatment workers with injuries that are not definitively tied to a work accident may be billed either under group health insurance plans or under WC. We document that there is significant reclassification of injuries from group health plans into WC, or "claims shifting", when the financial incentives to do so are strongest. In particular, we find that injuries to workers enrolled in capitated group health plans (such as HMOs) see a higher incidence of their claims for soft-tissue injuries under WC than under group health, relative to those in non-capitated plans. Such a pattern is not evident for workers with traumatic injuries, which are easier to classify specifically as work related. Moreover, we find that such reclassification is more common in states with higher WC fees, once again for soft tissue but not traumatic injuries. Our results imply that a significant shift towards capitated reimbursement, or reimbursement reductions, under $\mathrm{GH}$ could lead to a large rise in the cost of WC plans
\end{abstract}

Olesya Fomenko

Workers Compensation Research Institute

955 Massachusetts Ave

Cambridge, MA 02460

ofomenko@wcrinet.org

Jonathan Gruber

Department of Economics, E52-434

MIT

77 Massachusetts Avenue

Cambridge, MA 02139

and NBER

gruberj@mit.edu 
A common feature of health care systems around the world is parallel reimbursement structures, under which providers can to some extent choose who will reimburse them for patient care. In nations with large government run health care systems, parallel reimbursement arises from the fact that many providers deliver care both under the government system and to patients who pay (or are insured) privately. In such a situation, physicians can steer episodes of care towards their private practices or to the government financed care, depending on the relative rewards of each system and patient preferences. As a result, changes in reimbursement though one system can affect not only the care of patients in that system, but the allocation of patients across systems. We label such a phenomenon "claims-shifting".

Such an issue arises in the U.S. context as well, however, because of important fragmentation in how providers are reimbursed for the same patient. One source of such fragmentation is the Workers Compensation program, which reimburses the medical care of those who are injured at work, and which pays $\$ 30$ billion per year in medical costs. ${ }^{1}$ Most workers are covered for their non-work related injury through a group health insurance plan, while work-related injuries are covered through their employers' workers compensation insurance plans.

The workers' compensation systems rely heavily on the treating provider to determine whether or not an injury is work related or not. The physicians who make this determination

\footnotetext{
${ }^{1}$ National Academy of Social Insurance estimates based on data received from state agencies, the U.S. Department of Labor, A.M. Best, and the National Council on Compensation Insurance.
} 
are compensated differentially by the two systems. As a result, when a provider has discretion in categorizing a given injury as work-related or not, the relative compensation across the two systems can impact that categorization.

This issue arises in a variety of contexts in the U.S. as well as internationally. Within Workers' Compensation, in addition to the parallel reimbursement systems with group health, there are also parallel reimbursement systems with the most important government insurance programs, Medicare and Medicaid. There are also parallel reimbursement systems run between auto insurance, which includes medical costs associated with auto accidents, and group health, Medicare and Medicaid. And a number of physicians may not "accept assignment" for particular Medicare patients, allowing the provider to move back and forth between Medicare rates and potentially higher rates that can be charged to self-paying elderly patients.

In this paper, we explore whether the relative reimbursement of physicians under the group health care $(\mathrm{GH})$ and workers compensation (WC) systems impacts the way in which injuries are classified by providers. In particular, we consider two important differences between the reimbursement of GH and WC systems.

The first is the capitation of GH payments. Under a capitated system, providers are not reimbursed on the margin for their care to patients. This contrasts with the fee-for-service system under which providers are reimbursed in the WC system. On the margin, therefore, some providers may prefer to classify patients as WC than as GH in order to be marginally reimbursed for their care. 
The second is variation in the fees paid under the WC system. Providers reimbursed for GH under a FFS system may compare the fees that they can get paid under GH to those under WC. As a result, higher fees often paid in WC will lead to an incentive to shift cases to the WC system.

Of course, a concern with both of these comparisons is that patients who are covered by capitated plans, or those in states with higher WC fees, may differ from patients who are covered by FFS or in lower-fee states. To address that concern, we exploit the fact (long-used in the workers compensation research literature) that it is much more difficult to classify some injuries as work related than others. In particular, traumatic injuries such as contusions or fractures are hard to label as work-related when they didn't actually occur at work. On the other hand, sprains and strains are more readily shifted across the work-nonwork margin in terms of labeling. Our empirical approach is therefore to use traumatic injuries as a control group to pick up any omitted factors that bias the comparison for sprains and strains.

To carry out this analysis, we draw on a several databases. The base data for our analysis is the MarketScan ${ }^{\circledR}$ Commercial Claims and Health and Productivity Management databases from Truven. These data sets contain information on both workers compensation and group health claims for a large geographically diverse set of workers. We use these data to model the classification of medical claims into GH and WC.

Our results suggest that, on average, physicians do use their classification discretion to increase incomes by shifting cases to WC when it is more profitable to do so. In particular, we find that a sprain or strain for a worker in a capitated GH system is $9 \%$ more likely to be classified as WC, while there is no corresponding effect for traumatic injuries. Among those in 
FFS GH systems, we also find that a one standard deviation rise in WC reimbursement leads to $5 \%$ more cases being classified as WC. These findings have important implications for the interaction of health care systems as the U.S. transitions more fully to a capitated health care system or value-based reimbursements.

Our paper proceeds as follows. In part I, we describe relevant aspects of the parallel GH and WC systems and how relative incentives might impact classification across them. In Part II, we discuss the unique data that we bring to bear on this question, and Part III focuses on the empirical strategy that we employ. Part IV presents the results for how capitation of GH impacts the classification decision, and the impact of WC fees on classification of fee-for-service patients. Part $\mathrm{V}$ concludes with a discussion of policy implications.

\section{Part I: Group Health and Workers Compensation: Parallel Health Care Reimbursement} Reimbursement Structure under Workers' Compensation Relative to Group Health

Most workers in the United States, particularly those at large firms, obtain health insurance on their jobs through Group Health programs. Among workers in larger firms, there is often a choice of several insurance options, while in smaller firms there is typically little choice. $^{2}$

GH insurance plans can differ along a wide variety of dimensions. One is the freedom of patients to choose their providers; there is a growing use of "limited network" plans that restrict the ability of patients to choose their provider. Another is patient cost-sharing; plans

\footnotetext{
${ }^{2}$ In 2010, the endpoint of our sample, 44\% of firms with more than 200 employees offer more than one plan, compared to only 15\% of firms with fewer than 200 employees (Kaiser Family Foundation, 2010).
} 
can vary widely in their use of deductibles, copayments, coinsurance or other forms of costsharing. Yet another, largely invisible to the patient, is how plans reimburse their providers. Broadly speaking, under a pure Fee-for-Service system, providers are reimbursed restrospectively for the costs of their care. The level of reimbursement can vary widely, however, depending on the negotiated rates between insurers and providers.

Alternatively, providers may be paid under some form of capitated system. While such systems vary widely, the key distinction is that providers are to some extent paid prospectively rather than retrospectively, so that on the margin they are not fully compensated for the care that they deliver to patients. Under the traditional Health Maintenance Organization (HMO) model, for example, providers receive a salary or capitated payment that does not depend on the level of care that they deliver; modern HMOs can vary in the extent to which providers are capitated.

At the same time, almost all workers are covered for work injuries through the Workers Compensation system. The WC system in all states pays providers under a FFS system. In 43 states, workers' compensation prices are regulated by statutory regulations (i.e., fee schedules). In states with specified workers' compensation fee schedule rates, workers' compensation prices are either paid at the statutory fee schedule rate or at a negotiated rate where the fee schedule is often used as a benchmark. ${ }^{3}$ In the remaining states, workers' compensation prices for out-of-network services are often paid at what the provider charges or

\footnotetext{
3 The negotiated rates are often discounted prices below the fee schedule rates; sometimes they can be above the fee schedule rates (if the regulation allows), especially when the workers' compensation fee schedule rates in a state are substantially lower than the prices paid by other large payors (such as group health and Medicare).
} 
some notion of usual and customary charges in the area, while in-network providers are paid at a negotiated rate.

This fee schedule differs substantially across the states. Figure 1 shows that a number of states (California, Massachusetts, Florida, North Carolina, New York, and Hawaii) established their workers' compensation fee schedule rates, on average across all types of professional services, to be within 15 percent of Medicare rates as of July 2011. On the other hand, five states (Alaska, Illinois, Idaho, Delaware, and Oregon) set their workers' compensation fee schedule rates at levels more than double Medicare at the state level. Also, according to WCRI Medical Price Index for Workers' Compensation, Seventh Edition (Yang and Fomenko, 2015), the overall level of prices paid in the highest-price study state, Wisconsin, was more than three times the level in Florida, the lowest-price study state.

According to previously published WCRI studies, in many states, workers' compensation pays higher prices than group health (Fomenko and Victor, 2013 and Fomenko, 2013). For common surgeries such as knee arthroscopy, as Figure 2 shows, the prices paid under workers' compensation were higher than the prices paid by group health insurers in almost all study states, and, in some states, workers' compensation prices were two to four times higher than group health prices (Fomenko and Victor, 2013). Also, the interstate variation in the prices paid in workers' compensation was substantial and much more variable than the interstate variation in the group health prices paid for the same services. For office visits, the study reported smaller variation in the prices paid between two types of payors. ${ }^{4}$

\footnotetext{
${ }^{4}$ Another WCRI study showed that, in two thirds of the study states, workers' compensation hospital outpatient payments related to common surgeries were higher than those paid by group health insurers, and, in half of the
} 
In most states, WC pays for medical care when the injury "arises out of and in the course of employment". ${ }^{5}$ The central issue for our analysis is the determination of whether injuries are work-related. The initial determination is not done centrally, but rather by the physician who also treats the worker's injury. The providers' decision is evident from where s/he sends the bill to be paid - the WC insurer or the GH insurer. The WC payer sometimes disagrees with the provider's classification of an injury and disputes whether the injury is workrelated. In this case, the worker may either ask the provider to bill the $\mathrm{GH}$ insurer, or file a request for an administrative hearing from the state regulatory agency.

To the extent that an injury is unambiguously work-related or not work-related, there is no issue of physician classification; the physicians will simply submit their bills under the relevant system. For example, determining if a condition is work-related is relatively straightforward for a patient who presents with a fractured tibia-the cause of the fracture is usually identified with a specific event, and determining whether or not that event was workrelated is also relatively straightforward.

By contrast, the cause may be less certain for a patient presenting with a soft tissue condition (e.g., non-specific back pain or strain/sprain of knees or shoulders). For example, the medical literature shows that there is often little consensus about identifying the precise cause of back pain in a specific individual. Some cases of back pain are said to be caused by a specific event (e.g., lifting a heavy object); others are said to be caused by repetitive motion that wears down parts of the back architecture; still other cases are believed to be caused by the wear and

study states, the workers' compensation and group health difference for shoulder surgeries exceeded $\$ 2,000$ (or was at least 43 percent higher) (Fomenko, 2013).

${ }^{5}$ This language is present in almost all state statutes. See for example Missouri Revised Statutes, Chapter 287.020.3(1). 
tear of the aging process; and others are thought to result from latent congenital defects in the architecture of the back that emerge at some point in time. However, it often is uncertain about the true cause or causes-hence the professional judgment of the treating physician is heavily relied on for making this determination.

Of course, within each of these injury categories, there may be significant variation in the difficulty of determining whether an injury is work related. We are not claiming that this is a perfect distinction between certain and vague injuries. Rather, we are arguing on a priori grounds that it is much harder to reclassify traumatic injuries as work related when they are not, compared to sprains and strains.

Incentives for Claims Shifting

The structure of the parallel WC and GH systems can provide incentives for claims shifting by physicians in two ways. First, GH systems that are capitated do not reimburse physicians on the margin for the amount of care that they deliver to patients. In contrast, the FFS WC system does reimburse on the margin. Therefore, a physician who can profitably extend treatment of a patient under a FFS system would prefer that reimbursement to capitation. Physicians with some discretion over whether to code an injury as work-related will therefore try to do so in cases where they can provide profitable care on the margin.

Second, among those patients who are reimbursed on a FFS basis by both GH and WC systems, physicians can face very different prices for the marginal treatment. As noted above, for example, the WC system reimburses knee surgeries at a rate well above the GH system, and this differential varies by state. Once again, a physician with discretion over coding an injury as 
work related or not will have a stronger incentive to do so when they are relatively well reimbursed by WC.

The consequences of such reclassification from GH to WC are sizeable. If just 1 percent of group health cases with soft tissue conditions (including non-specific back pain) were shifted to workers' compensation, workers' compensation costs in a state like Pennsylvania could increase by nearly $\$ 35,000,000 .{ }^{6}$ The increase would be higher in a state like California (more than $\$ 80,000,000)$. Even in a smaller state like lowa, the added workers' compensation costs would be noticeable (about $\$ 9,000,000$ or about 1.8 percent of total benefits paid).

Of course, we are not claiming that such financial incentives are a perfect determinant of physician claiming decisions. Physicians will face a variety of other considerations in categorizing injuries, and may not focus primarily on the financial differences. The purpose of this paper is to investigate whether such financial incentives matter on the margin.

\section{Previous Literature}

There is a large previous literature on the impact of incentives provided under the Workers' Compensation system on patient and provider behavior. One strand of the literature focuses on the impact of WC benefits differentials on injury claiming and duration; for a detailed review see Butler et al. (2013). While not closely related to our work, this literature does introduce an important distinction that we make use of in our empirical strategy: the difference between soft-tissue injuries (over which there is more classification discretion) vs. traumatic injuries (over which there is less discretion). Perhaps the most famous application is

\footnotetext{
${ }^{6}$ To obtain the cost impact estimates, we used average medical and income benefit payments per soft-tissue claim in a particular state.
} 
to the documentation of the "Monday Effect," whereby a higher share of injuries claimed on Mondays are soft-tissue injuries, presumably delayed claiming of non-work injuries that occurred over the weekend (Smith, 1990).

More related is a smaller previous literature on provider responses to WC payments. There are some studies which document more intensive treatment of WC patients when fees are higher; e.g. Yee, Pizer, and Fomenko (2015) found that surgeons did more back surgery on injured workers in states where they were paid relatively more by workers' compensation payors. There is also evidence that surgeons provide more services to patients covered by more generous insurance types and plans (Yee, 2012; Yip, 1998). ${ }^{7}$ More broadly a large literature focusing on Medicare documents the responsiveness of patient treatment to higher fees, with somewhat mixed results; some studies claim that higher fees lead to more intensive treatment, while others suggest offsetting reductions in treatment when fees rise due to physician income effects. A recent compelling study by Clemens and Gottleib (2015) strongly supports the former view.

There is very little work on the specific question on which we focus, reclassifying claims across providers in response to financial incentives. Initial evidence in Ducatman (1986) undertook a cross-sectional examination of eight federal shipyards with varying degrees of HMO penetration, and found that WC costs were higher at the shipyard with a larger HMO penetration. Butler et al. (1997) show that higher HMO penetration across states increase the incidence of WC claims, and also find using data from one firm that workers comp claims are

\footnotetext{
${ }^{7}$ Yee (2012) showed that financial incentives related to ownership of ambulatory surgery centers (ASCs) led surgeons to provide more surgery for patients covered by commercial (group health) indemnity plans and workers' compensation than for patients covered by other plans, such as Medicaid, commercial health maintenance organizations (HMOs), and preferred provider organizations (PPOs). Yip (1998) found that Medicare fee reduction increased the volume of surgical procedures on group health insured patients.
} 
higher for workers enrolled in an HMO plan. On the other hand, Zwerling et al. (1991) find that WC claims are no higher for an HMO plan than a FFS plan for Boston postal workers. The mixed response across these studies may reflect the fact that there are important differences across areas with more $\mathrm{HMO}$ penetration, or between enrollees in $\mathrm{HMO}$ and Fee for Service plans. Our empirical strategy provides a test of these alternative explanations, as well as considering multiple approaches to testing the claims-shifting hypothesis.

\section{Part II: Data Construction}

Data

This analysis relies principally on workers' compensation and group health medical data coming from the Truven Health MarketScan Commercial Claims and Health and Productivity Management Databases ${ }^{8}$, a large commercial collection of databases. The Truven database is based on a large convenience sample of patients where the data was provided by health insurers and self-insured employers. It includes individuals employed by mostly large employers and insured or administered by one of approximately 100 group health plans. The database is unique in that, for a given employee, it shows whether a given medical encounter (visit) was paid for by group health or workers' compensation. This is key for the study since it provides the basis for determining which treatments were paid under which insurance policy.

The strength of these data are their size and the unique availability of both GH and WC data; these are the only national data of which we are aware that provides this information. The weakness is that this is a convenience sample. There is no reason, however, to think that

\footnotetext{
${ }^{8}$ Copyright $^{\circledR} 2012$ Truven Health Analytics Inc. All rights reserved.
} 
the particular convenience sample employed here would in any way bias our estimates of claims-shifting.

For the sampled employees, the group health section of the database contains patient information including demographic characteristics (e.g., age, gender, and geographic location), employment information (e.g., employment status and industry) and group health plan enrollment details (e.g., dates of coverage and type of private insurance plan). This database links patient information with detailed medical transaction (i.e., encounter) level data for all services reimbursed under group health plans regardless of the setting (i.e., outpatient or hospital) or provider type. The medical transaction data contains detailed information for each medical encounter, including the type of services provided during the encounter, medical diagnosis recorded, and payment amounts for each rendered service.

This database also includes workers' compensation claim data for most of the same individuals, if they had workers' compensation claims. Unlike group health medical encounter data, workers' compensation data do not contain detailed encounter level information for medical services paid by workers' compensation insurance; instead, workers' compensation data contains aggregated workers' compensation claim (i.e., episode) level data. For example, the diagnostic and payment information for all services provided to an injured worker and compensated by workers' compensation insurance is summarized at the claim (episode) level, with information on primary diagnosis (or injury type) and total medical payments for all services provided and paid as of the time of data collection. 
We also rely to some extent on the Detailed Benchmark/Evaluation (DBE) database collected by the Workers Compensation Research Institute (WCRI). ${ }^{9}$ We used these data for two purposes. The first is to examine descriptive statistics on the distribution of workers' compensation claims by number of office visits and to compare with group health data; we use these data because unlike the workers' compensation data in the main database, these data contain detailed data on the date and type of services rendered. The second is to measure our key fee variable, the workers compensation payment associate with an office visit.

\section{Sample Definition}

We select a sample of workers who had one of two types of injuries which (a) are frequent sources of workers' compensation claims and (b) represent very different degrees of difficulty in establishing the work-relatedness of the injury. The first type of injury includes certain soft tissue conditions, such as back pain, knee pain, and shoulder pain. For these conditions, work-relatedness may be uncertain. The second type of injury includes injuries by trauma, including fractures, lacerations, and contusions. For these conditions, it is much more straightforward to determine whether the injury was work-related or not, since the timing of the injury is better identified. According to our data, these two sets of diagnoses comprise more than $70 \%$ of workers compensation claims; the vast majority of the remaining injuries in the database are not well specified occupational or cumulative injuries.

\footnotetext{
${ }^{9}$ The DBE data were from 26 large insurers, self-insurers, state funds, and third-party administrators in the study states. Other WCRI studies show that the DBE database is reasonably representative of the state systems studied, but not in all states. For methods used to assess the representativeness of sample data in the DBE database, please refer to CompScope ${ }^{T M}$ Benchmarks, 15th Edition (Belton et al., 2015).
} 
We select a sample of workers with one of these two types of injuries that occurred over the 2008-2010 period. For patients whose care was paid for by the group health insurers, to identify a worker as having a particular medical condition, we relied on the primary diagnosis code associated with the first and second office visits or emergency room visits (we discuss the restriction to two visits below). For workers' compensation patients, since the available data do not have visit-level diagnosis records, we used injury type assigned by the workers' compensation claims adjuster. Sometimes this was assigned using the ICD-9 (International Classification of Diseases, 9th Revision) codes in the billing data. Other times it was assigned using standard workers' compensation industry codes for type of injury.

We restrict the analysis sample to full-time workers (about 86 percent of these injuries). We exclude employees who were older than 65 since they may also be covered by Medicare. We also exclude patients who may be undergoing ongoing treatment for an existing injury, in order to focus on new injuries. To do so we exclude from the sample to patients who received treatment for the same medical condition in the 24 months prior to the first claim that we observe during our study period. Further, to ensure that we are excluding patients who had such earlier care but were covered by another payer outside of the database or were uninsured, we exclude patients who did not have continuous medical insurance coverage with an employer captured in the database. Hence, we included workers with continuous group health insurance coverage and without treatment for the same medical conditions for the two years prior the onset of an episode, so the data used in this analysis covers years between 2006 and 2011. 
After these exclusions, the final sample consists of 156,535 observations. The means for this sample are presented in Table 1, separately for those claims under WC and those under GH. Roughly three-quarters of the claims are classified as Group Health. The observable characteristics of the employees whose claims are included in either category are fairly similar.

Dependent variable: did the treating doctor deem the condition to be work-related?

We seek to determine if the initial treating provider deemed the injury work-related or not. Since we do not directly observe the doctors' decisions, we infer the decision from whether a patient's care was paid under workers' compensation or group health. If the medical care was paid by workers' compensation, we assumed that the injury was deemed work-related by the treating doctor. If paid for by the group health insurer, we assumed that the treating doctor deemed the injury not to be work-related.

We assume that the provider forms a general impression for each patient of the expected future revenue from treating for his/her practice or for his/her clinic or hospital. This estimate is related to the expected severity of the injury as well as expected reimbursement rates for the necessary and auxiliary services that a provider or his/her group practice can render as part of the treatment. We expect that the initial treating physicians' decisions about work-relatedness are made near the beginning of the episode of care. The need to submit a bill certainly provides such motivation. This decision may occur at the first visit or at some other early visit. For the purposes of this study, we therefore examine whether the first two visits were paid by workers' compensation or group health. Hence we excluded patients that had fewer than 2 visits with diagnoses of one of the medical conditions of interest. 
The use of a 2 visit threshold confirms the diagnosis that serves as our sample selection criterion. In addition, we found only a very small share of WC cases with only one visit, so restricting to those with two or more GH visits imposes more uniformity on the samples. ${ }^{10}$ Below we show that the results are not very different if we had chosen a 1 or 3 visit threshold.

Table 2 shows the sample by type of injury and type of payer in our sample. In the full sample, $72 \%$ of claims are for soft tissue conditions, while $28 \%$ are for traumatic injuries, divided roughly equally into contusions, fractures/dislocations, and lacerations. Not surprisingly, there is a much higher share of traumatic injuries in the workers compensation sample; soft-tissue conditions are only $50 \%$ of WC paid claims, while they are $81 \%$ of the GH paid claims.

Independent Variables of Interest

For our first analysis, the key independent variable is the type of employer-sponsored group health plan that the worker had at the time of injury. The group health data contains eight types of health plans, including preferred provider organization (PPO), exclusive provider organization, non-capitated point-of-service, health maintenance organization (HMO), capitated or partially-capitated point-of-service, Comprehensive, Consumer-Driven Health Plan, and High Deductible Health Plan. Since all or some services under HMO and capitated or partially-capitated point-of-service plans are paid on a capitated basis, these plans are classified as capitated plans. The rest of the plan types comprise a non-capitated group. The

\footnotetext{
${ }^{10}$ Comparing the means and medians for the number of visits by those with WC and GH, we find that they match much better when restricting to at least $2 \mathrm{GH}$ visits. For example, the mean number of visits for patients with injuries by trauma under WC is 2.9, and the median is 2 . Looking at all GH patients, the mean is 1.3 and the median is 1 . But if we restrict to patients with a least two visits, the mean is 2.6 and the median is 2 .
} 
overwhelming majority of the patients in the capitated group have HMO type employerprovided insurance coverage, while the non-capitated plans are predominantly PPO and noncapitated point-of-service plans.

We then turn to an analysis of the impact of WC fees on patient classification. For this analysis the key independent variable is physician revenue for treating a workers' compensation patient. This variable was constructed, by adding payments for physician medical services during a second office visit for each patient. We use the revenue from all services at the second visit to approximate the expected future revenue estimate at the second visit. We evaluate below the sensitivity to using this particular fee measure.

In addition to evaluation and management services, among services rendered by physicians during a second office visit were minor radiology, diagnostic services and tests, physical therapy, drugs, etc. For each medical condition, these payment data were aggregated to the state-year level, by averaging across all patients with a particular condition in a given state. For injuries by trauma, the payments were aggregated for each of the three medical conditions (i.e., fractures, lacerations, and contusions) to the state-year level and then averaged to the injury by trauma level by applying frequency weights. Frequency weights are constant across all states and years and represent average relative occurrence of each injury within injury by trauma category. To control for outliers in the payment data, we excluded the highest and lowest 5 percent of payments before computing state and year averages for each medical condition. We assess the sensitivity to the physician revenue measure below.

The distribution of this measure across states is illustrated in Figure 3. Two points are apparent from this figure. First, the correlation of the office fee for trauma and soft-tissue 
injuries is quite high. Second, both series are very variable across states, with a high of over $\$ 200$ in Alaska and a low of under $\$ 100$ in Nevada.

As discussed earlier, physicians will respond not just to the level of the WC fee, but to the differential with respect to alternative reimbursement. Specifying the key independent variable as a differential, however, requires estimating a (noisy) measure of reimbursement under $\mathrm{GH}$ plans, and then imposing that this has an equal and opposite coefficient to the WC fee. Instead, we propose to include the alternative reimbursement in the regression as a freely estimated parameter, as discussed below.

\section{Part III: Empirical Strategy and Identification Concerns}

\section{Capitation and Case-Shifting}

Our first test for the impact of financial incentives on case-shifting is to examine whether workers enrolled in capitated GH plans are more likely to have their injuries categorized as work-related than are those workers enrolled in non-capitated GH plans. That is, we run regressions of the form:

$$
W C_{e p}=\alpha+\beta C A P_{p}+\delta X_{e}+\varepsilon_{e p}
$$

Where e indexes episode, and $\mathrm{p}$ indexes GH plans. WC is a dummy for whether episode e for an individual enrolled in GH plan $\mathrm{p}$ is categorized as a workers compensation claim. CAP is a dummy variable for whether the GH plan for that worker is capitated. If capitation causes more case-shifting, we should expect a positive coefficient $\beta$.

We also include a rich set of control variables for the patient experiencing the episode (X). This includes age (dummies for ages 18-34, 35-44, 45-54 and 55-64), gender, dummies for 
each state of residence, measures of previous medical use (described below), and the industry classification of the employer at the time of injury. ${ }^{11}$

A causal interpretation of the coefficient $\beta$ as the impact of capitation on case-shifting faces two types of selection concerns. The first is employee selection effects. That patients who chose to be covered by capitated plans may be different from patients who chose to be covered by fee for service plans. In particular, the past literature on managed care suggests that there is positive selection into such plans, with the plans attracting healthier patients on average. ${ }^{12}$ Such positive selection has an unclear impact on claims-shifting, depending on whether healthier enrollees are more or less likely to have work-related versus non workrelated injuries.

Moreover, capitated plans may differ along other dimensions, such as provider access or patient cost sharing. Capitated plans such as HMOs will typically restrict patient access to providers, which once again has an uncertain effect on claims-shifting. Such plans will also typically feature lower patient cost-sharing; for example, in 2010, only about one quarter of workers in HMOs had deductibles, while more than two-thirds of workers in other types of plans had a deductible (KFF, 2010). Since patients bear no costs for treatment under the WC system, patients in plans with more cost sharing would themselves prefer claims-shifting to WC. Since that is less likely in capitated plans, any patient influence on claims-shifting would bias against our hypothesized effect.

\footnotetext{
${ }^{11}$ Industry classification contains 11 categories: oil and gas extraction and mining; manufacturing of durable goods; manufacturing of nondurable goods; transportation, communication, and utilities; retail trade; finance, insurance, and real estate; services; agriculture, forestry, and fishing; construction; wholesale; and missing classification.

${ }^{12}$ See Glied (2000) for an early review of the literature in this area.
} 
The second is an employer selection effect; employers that offer capitated insurance plans are different from employers that offer only fee for service plans. The bias here is unclear, and depends on whether employers use capitated plans to best match the tastes of healthier workers, or uses them as a tool to control costs when workers are particularly sick.

We address these concerns in three ways in the empirical work. The first is with a set of controls for observable demographic and employer characteristics, as described above. The second is to control more directly for preinjury health status as captured by the level of medical utilization by each patient in the 24 months prior to the onset of the medical condition of interest (e.g., back strain or leg fracture). The control variables used are (1) whether the patient had none, one, or more hospital admissions, and (2) the number of office visits paid by group health plans for each patient in that preinjury 24-month period.

Finally, as noted above, we focus our estimation on those soft-tissue injuries which are likely to be subject to the most discretion of physicians, and compare the results for these injuries to traumatic injuries over which physicians have much less discretion in classification.

Table 3-4 illustrate the power of these approaches. Table 3 shows the distribution of age and gender by type of plan and type of injury. Overall, the distribution of age and gender is quite similar between capitated and non-capitated cases, but there are some small differences: the capitated sample is somewhat more female and slightly younger. Any differences between groups, however, is reflected equally in trauma and soft-tissue injuries: that is, the share of the sample that is age $55-64$ is $2 \%$ higher in non-capitated plans for both types of injury. This suggests that the comparison between types of injuries removes residual differences across groups. That is, a difference-in-difference comparison of soft tissue injuries versus traumatic 
injuries, in the capitated versus non-capitated sample, shows little difference in ex-ante characteristics.

Table 4 carries out this same type of comparison for our measures of prior utilization. There are larger differences here between capitated and non-capitated plans, but once again the difference-in-difference comparisons are fairly similar.

Of course, these comparisons along observable dimensions do not prove that there is no unobserved difference between enrollees that does not operate equally for both types of injuries. For this reason, we consider a second approach to illustrating that financial incentives impact case-shifting

Fees and Case-Shifting

Our second empirical approach is to focus on how fee differentials in the Fee-for-service sector impact the classification of workers into GH or WC. We focus in this analysis only on non-capitated plans because the marginal changes in WC fees are likely to be more significant, relative to capitated plans where there is already an enormous incentive to shift to WC. In addition, the capitated sample has sufficiently small cells by state that we are unable to produce sufficiently valid state-specific fee estimates.

Within the FFS sample, we run regressions of the form:

(2) $\quad W C_{\text {is }}=\alpha+\beta \mathrm{FEE}_{\mathrm{s}}+\delta \mathrm{X}_{\mathrm{i}}+\varepsilon_{\mathrm{ep}}$

Where $\mathrm{i}$ indexes individuals and $\mathrm{s}$ indexes states. $\mathrm{WC}$ and $\mathrm{X}$ are as above, and FEE is the WC fee measure described earlier. 
An advantage of including this approach in our analysis is that it is not subject to any bias from differential selection into capitated versus non-capitated plans. But this analysis introduces a new potential bias: state fee differentials may be correlated with unobservable determinants of WC classification. For example, states with higher underlying medical costs will have particularly high WC fees, and such states may be ones where injuries are more or less likely to be classified as work-related.

As above, we can partially address this concern through including demographic characteristics, employer characteristics, and past medical use in our set of control variables. In addition, as above, we can show differential impacts for soft tissue versus traumatic injuries to establish causality.

Ideally, we would control for state differences with state fixed effects, but we do not have enough WC fee changes in our narrow time window. Instead, we include as a control in the regression measures of the alternative fees available to physicians in the state, measured in two ways. The first is the group health payment for professional services provided during an office visit. This is computed similarly to the equivalent workers' compensation payment measure. The payment measures for group health for each state and year are computed based on payment data for patients with FFS plans included in the analysis sample as group health patients. This results in relatively small sample sizes in some states, especially for group health patients with lacerations, contusions, and fractures. On the other hand, WCRI DBE is used to compute workers' compensation measures, yielding larger sample sizes for the common workers' compensation injuries analyzed here. We therefore turn to a second administrative measure which is not subject to these measurement problems: the Medicare fee for a common 
office visit. For this measure we use Medicare fee schedule rates for a common office visit in 2009 published by Centers for Medicare and Medicaid Services.

To summarize, we present two alternative approaches to show that financial incentives impact claims-shifting from group health to workers compensation. Neither approach is perfect, but taken together they can provide a compelling test of whether financial incentives matter for claims-shifting to WC.

\section{Part IV: Results}

Capitation vs. FFS

In this section, we discuss the results from estimating equation (1), to examine the effect of capitation on the decision to classify injuries as workers compensation vs. group health. All regression standard errors are clustered at the plan level for this analysis.

The basic results are presented in Table 5 . The first column shows the results for softtissue conditions, while the second shows the results for injuries by trauma. In the first column we estimate a highly significant effect of capitation of 1.7 percent of cases. Starting from the mean of $19.1 \%$ of cases being categorized as WC, this is a large $9 \%$ increase in the number of cases from moving from FFS to a capitated system (as shown at the bottom of the table).

Importantly, the second column shows that there is not a comparable impact in the second column for traumatic injuries. We estimate an insignificant and wrong signed effect of 0.01 percentage points, which is very small relative to the nearly $50 \%$ mean for the share WC for these injuries. 
The coefficient on the control variables are virtually identical in the two columns. We find that the share of injuries deemed to be work-related are much higher in manufacturing and wholesaling than in the omitted category services. There is little variation by age. The results indicate that those who have seen providers less frequently in the past are more likely to have injuries categorized as work-related.

Fee Effects

We next turn to estimating equation (2), to model the impact of WC fees on caseshifting within the FFS population. The results are presented in Table 6. Here we show just the coefficients of interest. The top panel shows the results for soft-tissue injuries, while the second panel shows the results for trauma.

In the first column, we show our estimates from (2) with no additional controls for other state fee levels. We find a very strong effect of fee differentials on case-shifting for soft-tissue conditions. Each $\$ 100$ rise in WC fees is associated with a 3.65 percent percentage point rise in the share of cases that are classified as WC. This implies that a one standard deviation rise in WC fees (\$27) would raise the share of cases classified as WC by 0.99 percentage points (or $5.2 \%)$

The second panel shows the results from estimating this same model for traumatic injuries. The coefficient in this case is negative and highly insignificant. The magnitude is very small and suggests that a one standard deviation increase in WC fees (\$28) would lower the share of cases classified as WC by only 0.4 percentage points (and given that WC share is $50 \%$, 
WC volume will decrease by $0.21 \%$ ). Thus, once again, the results for traumatic injuries suggests that the estimates for soft-tissue injuries is causal.

In the next two columns, we include two different controls to capture the underlying cost of medical care in the state: the average group health reimbursement rate for the state, and the Medicare reimbursement rate for an office visit for the state. Adding the group health measure lowers the estimated coefficient on soft tissue conditions, while raising that on traumatic injuries, but the implied effects of a one-standard deviation increase in fees remains almost five times as large for soft tissue as for trauma. Adding the Medicare fee measure has little impact on the results.

We cannot interpret the coefficients on the GH and MC fees themselves, since they capture not just price effects of alternative payment systems but other factors of local markets and norms. In addition to the geographic variation in costs to the providers of delivering the services, such as the office practice costs (e.g., staff salaries and office rent) and the malpractice premiums, fees likely correlate with population density and diversity among other factors defining local behavioral norms. Group health reimbursement rates are also likely to reflect the relative market power of the providers and the payers (or their networks) in local markets. The key point here is that our results are robust to adding these controls (albeit somewhat smaller with the group health control).

\section{Sensitivity to Sample Definitions}

We made a number of potentially significant choices in constructing the sample for this analysis. In this section, we discuss the sensitivity to those sample definitions. Table 7 presents 
the findings in a summary format. Each column has four panels, which show the coefficients of interest from our two models, for soft-tissue and traumatic injuries. In the first column we show the preferred specification that we have discussed above.

First, our empirical strategy relies on those who have not had a previous illness of that type within the past 24 months. This is a fairly restrictive condition which limits sample size. In column (2) of Table 7 we show the results of reestimating both equations (1) and (2) using a narrower window of 12 months, which raises our sample size to 267,602 . This change reduces the coefficient on capitation in the soft-tissue regression, but the effect is actually larger relative to the share of cases paid by workers compensation; the effect for traumatic injuries remains insignificant and small. The fee coefficient remains roughly the same for soft-tissue conditions, implying a rising share relative to baseline, with the coefficient for trauma remaining wrong signed and insignificant.

Another concern is that the composition of trauma injuries varies across WC and GH patients. The vast majority of injuries by trauma in workers' compensation were contusions and lacerations, while the vast majority of injuries by trauma in group health were represented by fractures and dislocations. To ensure that our estimated effects are not driven by compositional differences in the easy-to-diagnose group between $\mathrm{WC}$ and $\mathrm{GH}$, we restrict our definition of this injury category to fractures and dislocations. In this case we actually get a larger negative coefficient on traumatic injuries in the capitation regression, and a positive but small effect on traumatic injuries in the fee regression; overall, the conclusions are similar.

Third, we imposed the condition that patients have two GH visits before they are included in our sample. As noted earlier, this allowed us to confirm the diagnosis for our 
analysis, as well as to allow for more comparability between cases considered for GH and WC.

In the next two columns of Table 7, we show the effect of alternative restrictions, including any patient with at least one visit, and also requiring 3 visits. Using any patient with at least one visit strengthens both our soft tissue results and traumatic injury results for capitation effects, but the difference between the two coefficients is similar; on the other hand, restricting to only three visits slightly weakens the percentage effect for soft tissue but drives the traumatic injury capitation coefficient larger and negative, so that once again the differential is similar. The fee coefficients across the types of injuries get closer when we restrict only to $3+$ visits, but the effect on soft tissue injuries remains three times as large as on traumatic injuries.

Finally, for the fee ratio work, we chose a particular physician revenue measure, which was the total revenue earned from the second physician visit. To asses sensitivity to the specification of the physician revenue measure, we used two other more conservative definitions-payment to physician for evaluation and management services and payment for common office visit (i.e., CPT 99213). The last two columns of Table 7 show that our fee results are very robust to these alternative measures; using the E\&M measure raises the soft tissue coefficient considerably, but the trauma coefficient becomes marginally significant as well, so that the gap between the two remains similar.

\section{Part V: Conclusions and Policy Implications}

In this paper we have explored the previously understudied issue of claims shifting within the U.S. health care system. We do so within the context of one of the nation's largest reimbursement systems for health care expenditures, the workers compensation program. This 
program spends about $\$ 30$ billion per year on a health care reimbursement system that runs parallel to coverage from employee group health insurance plans. As such, an important issue is whether the relative reimbursement across the two systems impacts the physician's willingness to categorize injuries within one system or another.

To explore this issue, we have studied two very different financial incentives. The first is the fact that WC programs reimburse providers on a fee-for-service basis, where care is reimbursed on the margin, while many $\mathrm{GH}$ plans feature a prospective capitation payment plan, where care is not reimbursed on the margin (either not at all, or not fully). This suggests that if claim-shifting is possible, we should see it operate most strongly for those patients enrolled in capitated $\mathrm{GH}$ plans. The second is the fact that the reimbursement that $\mathrm{WC}$ provides varies substantially across the states, so that incentives for claim shifting are largest in the states with the highest WC fees.

Both of these empirical approaches have strengths and weaknesses. Our key strategy for addressing the primary empirical issues is to compare effects for soft-tissue injuries to those for traumatic injury, as the former is much easier to reclassify as work-related than is the latter.

Taken together, the evidence from these empirical strategies suggests that claimsshifting is highly responsive to financial incentives. Patients enrolled in capitated $\mathrm{GH}$ plans are 9\% more likely to see their claims classified as WC rather than GH, compared to patients enrolled in fee-for-service GH plans. We also find that higher WC fees lead as well to more claims-shifting into WC, with a one standard deviation rise in WC fees resulting in $5.2 \%$ more cases being coded as work related. In each case, these effects are present for soft-tissue injuries and not for traumatic injuries. 
Our results have clear implications for the interaction of the group health and workers compensation markets. A key focus of recent reforms in the group health market is moving towards more capitated or "value-based" reimbursement mechanisms. This is particularly true of the Affordable Care Act, which promotes the formation of "Accountable Care Organizations" which would integrate and more fully capitate payments to systems of medical providers. Under such ACO arrangements, providers will have a strong incentive to find claims-shift to WC and its system for marginal reimbursement of medical claims.

These effects could be substantive in terms of both spending on Workers' Compensation and Group Health. For every $10 \%$ rise in the share of the population that is in capitated plans, we estimate that $\$ 208$ million in spending is shifted from GH to WC. Indeed, our results suggest that the incentive for claims-shifting due to capitation will grow as the market penetration of capitated plans grows and physicians have little other alternative for marginal reimbursements for care. In Table 8, we replicate our basic capitation results dividing our sample into three parts by the share of HMO enrollment by state, from KFF (2013). Column 1 presents the results for those states with the highest share of capitation in their state; in this sample HMO shares average $27 \%$ of group health plans. Column 2 presents the results for those states with the average level of HMO penetration; those states average $16 \%$ penetration. Column 3 focuses on the states with the lowest HMO penetration, averaging $5 \%$ of group health plans.

Strikingly, we find that the results for soft-tissue injuries are much stronger for the states with the highest rate of capitation. For those states, we estimate that there is a $31 \%$ increase in the odds of being classified as WC if a worker is in a capitated plan for a soft-tissue 
injury, with once again no effect for traumatic injury. For the other groups of states, there is little effect of reclassification.

These results are of course only suggestive; many features differ across these two sets of states besides $\mathrm{HMO}$ penetration. But they do suggest that as capitated arrangements widen in the group health market, there will be increasing pressure for claims-shifting. For the workers compensation program, this should be a major concern. Policy makers may want to consider either increasing care integration to include workers compensation systems, or workers compensation systems may need to parallel the rise in alternative capitated payment structures that we are seeing in the group health market. 


\section{References}

Belton, S., R. Dolinschi, E. Radeva, K. Rothkin, B. Savych, C. Telles, and R. Yang. 2015. CompScope ${ }^{\text {TM }}$ benchmarks, 15th edition. 15 vols. Cambridge, MA: Workers Compensation Research Institute.

Butler, R., H. Gardner, and N. Kleinman. 2013. Workers' compensation: Occupational injury insurance's influence on the workplace. In G. Dionne (ed.), Handbook of insurance (pp. 449-469). Springer-Verlag New York.

Butler, R., R. Hartwig, and H. Gardner. 1997. HMOs, moral hazard and cost shifting in workers' compensation. Journal of Health Economics 16 (2): 191-206.

Clemens, J. and J. Gottlieb. 2015. In the Shadow of a Giant: Medicare's Influence on Private Payment Systems. The Journal of Political Economy, forthcoming.

Ducatman, A. 1986. Workers' compensation cost shifting: A unique concern of providers and purchasers of prepaid health care. Journal of Occupational Medicine 28 (11): 1,1741,176 .

Fomenko, O. 2013. Comparing workers' compensation and group health hospital outpatient payments. Cambridge, MA: Workers Compensation Research Institute.

Fomenko, O., and T. Liu. 2012. Designing workers' compensation medical fee schedules. Cambridge, MA: Workers Compensation Research Institute.

Fomenko, O., and R. Victor. 2013. A new benchmark for workers' compensation fee schedules: Prices paid by commercial insurers? Cambridge, MA: Workers Compensation Research Institute.

Glied, Sherry (2000). "Managed Care," in Anthony Culyer and Joseph Newhouse, eds., Handbook of Health Economics. Amsterdam, Elsevier: 2000.

Yang, R., and O. Fomenko. 2015. WCRI medical price index for workers' compensation, seventh edition (MPI-WC). Cambridge, MA: Workers Compensation Research Institute.

Yee, C. 2012. Why surgeon owners of ambulatory surgical centers do more surgery than nonowners. Cambridge, MA: Workers Compensation Research Institute.

Yee, C., S. Pizer, and O. Fomenko. 2015. Why surgery rates vary. Cambridge, MA: Workers Compensation Research Institute.

Yip, W. 1998. Physician response to Medicare fee reductions: Changes in the volume and intensity of supply of coronary artery bypass graft (CABG) procedures for the Medicare and private sectors. Journal of Health Economics 17 (6): 675-699.

Zwerling, Craig, James Ryan and E. John Orav (1991). "Workers' Compensation Cost Shifting: An Empirical Study," American Journal of Industrial Medicine, 19, 317-325. 
bFigure 1: Workers' Compensation Premium over Medicare, July 2011

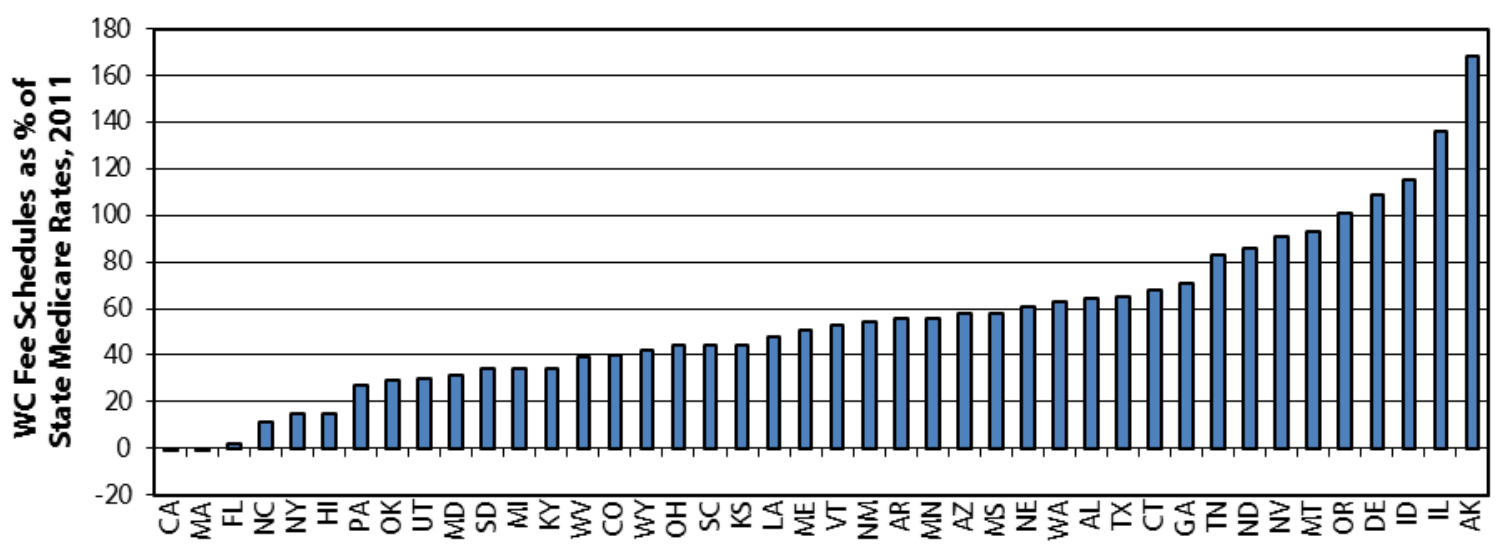

Source: Fomenko and Liu. 2012. Designing Workers' Compensation Medical Fee Schedules.

Notes: Delaware, Florida, Illinois, New York, Pennsylvania, and Texas have distinct workers' compensation fee schedules for different parts of the state. For each, a single statewide rate was created by averaging the different sub-state fee schedules using the percentage of employed persons in each sub-state region as weights. Medicare establishes distinct sub-state fee schedules in 14 states. For each, a single statewide rate was created using the same procedure. Illinois' September 2011 legislative change reducing the fee schedule rates by 30 percent is not reflected in this analysis. Since Ohio does not establish rates for the emergency services included in the marketbasket, the overall rate is based on the other seven service groups. Rhode Island is not included in this chart since it uses significantly different billing codes for one of the largest service groups, physical medicine. For more detail, see the technical appendix in Fomenko and Liu (2012). Also, the West Virginia workers' compensation fee schedule had an annual update, effective July 1,2011 , that is not reflected in this study. Moreover, fee schedule changes that took place after 2011 are not reflected in this figure. For example, effective January 2014, California transitioned to a RBRVS-based fee schedule. Also, Arizona implemented substantial increases in fee schedule rates for evaluation and management, physical medicine, and certain surgeries in October 2013.

Key: CPT: Current Procedural Terminology; WC: workers' compensation. 
Figure 2: Workers' Compensation and Group Health Median Prices Paid for a Common Knee Arthroscopy, 2009

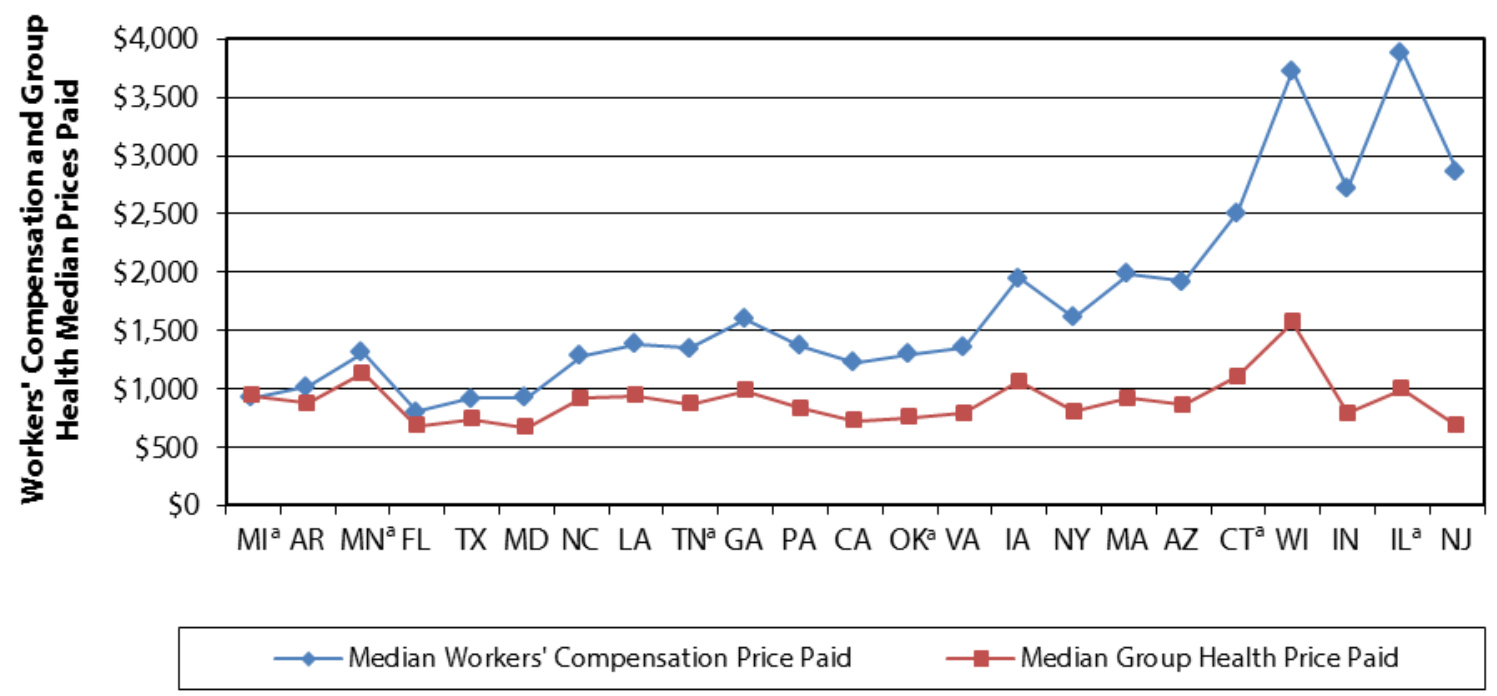

Source: Fomenko and Victor. 2013. A New Benchmark for Workers' Compensation Fee Schedules: Prices Paid by Commercial Insurers?

Note: CPT 29881.

a Implemented a double-digit fee schedule decrease for a common knee arthroscopy (CPT 29881) from 2009 to 2012

Key: CPT: Current Procedural Terminology. 
Table 1: Descriptive Summary of the Analysis Variables

\begin{tabular}{|c|c|c|c|c|}
\hline \multirow{2}{*}{ Variable } & \multicolumn{2}{|c|}{ WC } & \multicolumn{2}{|c|}{ GH } \\
\hline & Mean & St.dev & Mean & St.dev \\
\hline \multicolumn{5}{|l|}{ Industry } \\
\hline Oil \& Gas Mining & 0.002 & 0.044 & 0.012 & 0.111 \\
\hline Manufact., Durable & 0.533 & 0.499 & 0.491 & 0.500 \\
\hline Manufact., Nondurable & 0.220 & 0.414 & 0.163 & 0.369 \\
\hline Transport, Communic. & 0.139 & 0.346 & 0.128 & 0.334 \\
\hline $\begin{array}{l}\text { Finance, Insurance, Real } \\
\text { Estate }\end{array}$ & 0.003 & 0.055 & 0.061 & 0.240 \\
\hline Services & 0.073 & 0.261 & 0.075 & 0.264 \\
\hline Wholesale & 0.000 & 0.008 & 0.000 & 0.020 \\
\hline Missing & 0.029 & 0.168 & 0.069 & 0.253 \\
\hline \multicolumn{5}{|l|}{ Demographics } \\
\hline Age: 18-34 & 0.142 & 0.349 & 0.144 & 0.351 \\
\hline Age: $35-44$ & 0.263 & 0.440 & 0.263 & 0.440 \\
\hline Age: 45-54 & 0.391 & 0.488 & 0.390 & 0.488 \\
\hline Age: 55-64 & 0.204 & 0.403 & 0.204 & 0.403 \\
\hline Male & 0.706 & 0.456 & 0.655 & 0.475 \\
\hline Female & 0.294 & 0.456 & 0.345 & 0.475 \\
\hline \multicolumn{5}{|c|}{ Medical history (based on past 24 months) } \\
\hline No admissions & 0.909 & 0.287 & 0.906 & 0.291 \\
\hline One admission & 0.072 & 0.259 & 0.074 & 0.262 \\
\hline 2 or more admissions & 0.018 & 0.135 & 0.020 & 0.138 \\
\hline 0-4 physician visits & 0.370 & 0.483 & 0.318 & 0.466 \\
\hline 5-12 physician visits & 0.400 & 0.490 & 0.442 & 0.497 \\
\hline 13-24 physician visits & 0.181 & 0.385 & 0.192 & 0.394 \\
\hline $\begin{array}{l}25 \text { or more physician } \\
\text { visits }\end{array}$ & 0.049 & 0.216 & 0.049 & 0.215 \\
\hline Number of observations & 42940 & & & 113595 \\
\hline
\end{tabular}


Table 2: Sample Size and Composition, by Type of Injury and Type of Payer

\begin{tabular}{|c|c|c|c|c|c|c|}
\hline \multirow{2}{*}{$\begin{array}{l}\text { Medical } \\
\text { Conditions }\end{array}$} & \multicolumn{2}{|c|}{ Full Sample } & \multicolumn{2}{|c|}{ Group Health Paid } & \multicolumn{2}{|c|}{$\begin{array}{c}\text { Workers' } \\
\text { Compensation Paid }\end{array}$} \\
\hline & $\begin{array}{c}\text { Number } \\
\text { of } \\
\text { Patients }\end{array}$ & Percent & $\begin{array}{c}\text { Number of } \\
\text { Patients }\end{array}$ & Percent & $\begin{array}{c}\text { Number } \\
\text { of } \\
\text { Patients }\end{array}$ & Percent \\
\hline Contusion & 11,941 & $8 \%$ & 3,008 & $3 \%$ & 8,933 & $21 \%$ \\
\hline Fracture/dislocation & 17,057 & $11 \%$ & 14,200 & $13 \%$ & 2,857 & $7 \%$ \\
\hline Laceration & 14,600 & $9 \%$ & 4,860 & $4 \%$ & 9,740 & $23 \%$ \\
\hline $\begin{array}{l}\text { Soft tissue } \\
\text { conditions }\end{array}$ & 112,937 & $72 \%$ & 91,527 & $81 \%$ & 21,410 & $50 \%$ \\
\hline Grand total & 156,535 & $100 \%$ & 113,595 & $100 \%$ & 42,940 & $100 \%$ \\
\hline
\end{tabular}

Figure 3: Distribution of the Workers' Compensation Payments for Physician Services Provided During a Second Office Visit

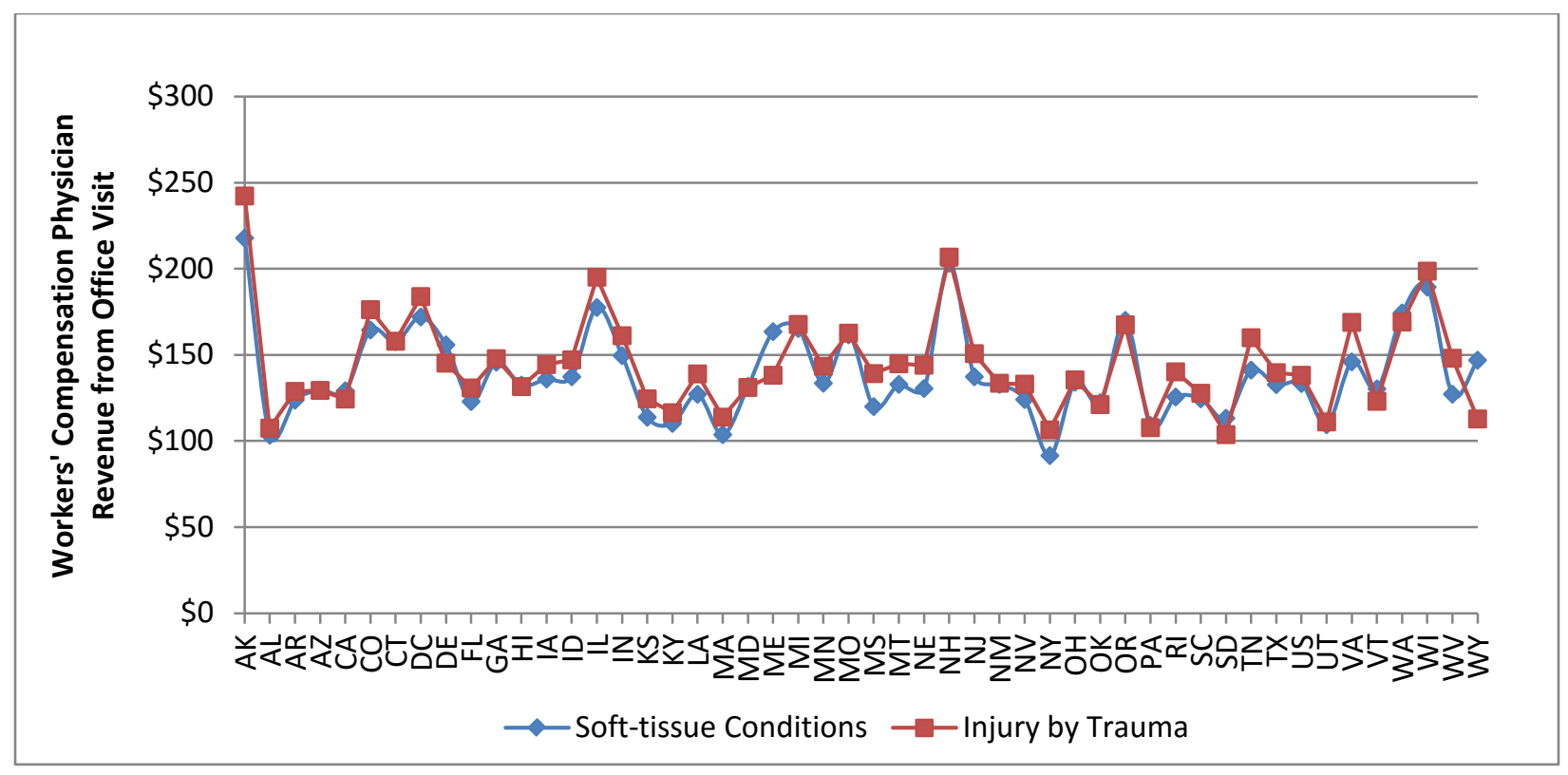


Table 3: Age and Gender among Group Health and Workers' Compensation Patients, by Type of Group Health Plan and Medical Condition

\begin{tabular}{|c|c|c|c|c|c|c|}
\hline & Male & Female & Age: 18-34 & Age: $35-44$ & Age: $45-54$ & Age: $55-64$ \\
\hline Non-capitated & $67 \%$ & $33 \%$ & $14 \%$ & $26 \%$ & $39 \%$ & $21 \%$ \\
\hline Injury by trauma & $69 \%$ & $31 \%$ & $15 \%$ & $25 \%$ & $39 \%$ & $22 \%$ \\
\hline Soft tissue conditions & $67 \%$ & $33 \%$ & $14 \%$ & $26 \%$ & $40 \%$ & $20 \%$ \\
\hline Capitated & $65 \%$ & $35 \%$ & $15 \%$ & $30 \%$ & $37 \%$ & $19 \%$ \\
\hline Injury by trauma & $67 \%$ & $33 \%$ & $15 \%$ & $29 \%$ & $37 \%$ & $20 \%$ \\
\hline Soft tissue conditions & $64 \%$ & $36 \%$ & $14 \%$ & $31 \%$ & $37 \%$ & $18 \%$ \\
\hline Grand total & $67 \%$ & $33 \%$ & $14 \%$ & $26 \%$ & $39 \%$ & $20 \%$ \\
\hline
\end{tabular}

Note: Underlying data include group health and workers' compensation patients included in the final analysis sample, grouped by employer-sponsored health insurer and medical condition. For more information on the construction of the analysis sample, refer to the "Data" section.

Table 4: Distribution of Medical Services (a proxy for preinjury health status) in the 2 Years Prior to Injury, by Type of Group Health Plan and Medical Condition

\begin{tabular}{|c|c|c|c|c|c|c|c|}
\hline & \multicolumn{3}{|c|}{$\begin{array}{c}\text { Number of Group Health } \\
\text { Inpatient Admissions }\end{array}$} & \multicolumn{4}{|c|}{$\begin{array}{l}\text { Number of Office Visits in } 24 \text { Months Prior } \\
\text { to Injury }\end{array}$} \\
\hline & 0 & 1 & 2 or More & $0-4$ & $5-12$ & $13-24$ & $25+$ \\
\hline Non-capitated & $91 \%$ & $7 \%$ & $2 \%$ & $34 \%$ & $43 \%$ & $18 \%$ & $5 \%$ \\
\hline Injury by trauma & $89 \%$ & $8 \%$ & $2 \%$ & $34 \%$ & $40 \%$ & $19 \%$ & $6 \%$ \\
\hline Soft tissue conditions & $91 \%$ & $7 \%$ & $2 \%$ & $34 \%$ & $44 \%$ & $18 \%$ & $4 \%$ \\
\hline Capitated & $90 \%$ & $8 \%$ & $2 \%$ & $29 \%$ & $45 \%$ & $21 \%$ & $5 \%$ \\
\hline Injury by trauma & $88 \%$ & $9 \%$ & $3 \%$ & $27 \%$ & $42 \%$ & $23 \%$ & $8 \%$ \\
\hline Soft tissue conditions & $91 \%$ & $8 \%$ & $2 \%$ & $29 \%$ & $47 \%$ & $20 \%$ & $4 \%$ \\
\hline Grand total & $91 \%$ & $7 \%$ & $2 \%$ & $33 \%$ & $43 \%$ & $19 \%$ & $5 \%$ \\
\hline
\end{tabular}


Table 5: Effect of Capitated Group Health Coverage on the Number of Cases Deemed Work-Related and Paid by Workers' Compensation

\begin{tabular}{|c|c|c|}
\hline & $\begin{array}{l}\text { Soft-tissue } \\
\text { conditions }\end{array}$ & Injury by trauma \\
\hline \multirow{2}{*}{ Capitated plans } & $0.0168^{\star *}$ & -0.0001 \\
\hline & $(0.0069)$ & $(0.0105)$ \\
\hline State fixed effects & Yes & Yes \\
\hline Year fixed effects & Yes & Yes \\
\hline \multicolumn{3}{|l|}{ Industry } \\
\hline \multirow{2}{*}{ Oil \& gas extraction, mining } & $-0.0422^{\star *}$ & $0.1111^{\star \star \star}$ \\
\hline & $(0.0123)$ & $(0.0119)$ \\
\hline \multirow{2}{*}{ Manufacturing, durable } & $0.1083^{\star \star \star}$ & $0.4516^{\star \star \star}$ \\
\hline & $(0.0099)$ & $(0.0087)$ \\
\hline \multirow{2}{*}{ Manufacturing, nondurable } & $0.1825^{\star \star \star}$ & $0.5153^{\star \star \star}$ \\
\hline & $(0.0111)$ & $(0.0166)$ \\
\hline \multirow{2}{*}{ Transportation, communications, utilities } & $0.1003^{\star \star}$ & $0.5632^{\star \star \star}$ \\
\hline & $(0.0314)$ & $(0.0205)$ \\
\hline \multirow{2}{*}{ Finance, insurance, real estate } & $-0.0659 * \star *$ & $0.0446^{\star \star \star}$ \\
\hline & $(0.0087)$ & $(0.0127)$ \\
\hline \multirow{2}{*}{ Wholesale } & $0.0914^{\star \star \star}$ & $0.4621^{\star \star \star}$ \\
\hline & $(0.0194)$ & $(0.0469)$ \\
\hline \multirow{2}{*}{ Missing industry } & $0.0239+$ & $0.1982^{\star \star \star}$ \\
\hline & $(0.0131)$ & $(0.0197)$ \\
\hline \multicolumn{3}{|l|}{ Demographics } \\
\hline \multirow{2}{*}{ Age: 35-44 } & -0.0073 & $0.0350^{\star \star \star}$ \\
\hline & $(0.0072)$ & $(0.0062)$ \\
\hline \multirow{2}{*}{ Age: $45-54$} & $-0.0150^{\star \star}$ & $0.0464^{\star \star \star}$ \\
\hline & $(0.0045)$ & $(0.0050)$ \\
\hline \multirow{2}{*}{ Age: 55-64 } & $-0.0200^{\star *}$ & $0.0637^{\star \star \star}$ \\
\hline & $(0.0081)$ & $(0.0101)$ \\
\hline \multirow{2}{*}{ Male } & $0.0136^{*}$ & 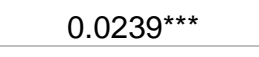 \\
\hline & $(0.0059)$ & $(0.0062)$ \\
\hline \multicolumn{3}{|l|}{ Medical history (based on past 24 months) } \\
\hline \multirow{2}{*}{ No admissions } & 0.0097 & $0.0656^{\star \star \star}$ \\
\hline & $(0.0096)$ & $(0.0133)$ \\
\hline \multirow{2}{*}{ One admission } & $0.0180^{\star *}$ & $0.0200^{\star \star *}$ \\
\hline & $(0.0070)$ & $(0.0037)$ \\
\hline \multirow{2}{*}{ 0-4 physician visits } & -0.0138 & $0.1191^{\star \star \star}$ \\
\hline & $(0.0201)$ & $(0.0210)$ \\
\hline \multirow{2}{*}{ 5-12 physician visits } & $-0.0460^{\star \star \star}$ & $0.0781^{\star \star \star}$ \\
\hline & $(0.0100)$ & $(0.0168)$ \\
\hline \multirow{2}{*}{ 13-24 physician visits } & 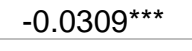 & $0.0543^{\star \star \star}$ \\
\hline & $(0.0034)$ & $(0.0123)$ \\
\hline
\end{tabular}


$\%$ of soft-tissue cases paid by workers' compensation (vs. group health payors)

Estimated increase in the \% of workers' compensation soft-tissue cases for capitated vs.

non-capitated group health plans

$8.80 \%$

$\%$ of injury by trauma cases paid by workers'

compensation (vs. group health payors)

$50.00 \%$

Estimated increase in the \% of workers'

compensation injury by trauma cases for capitated

vs. non-capitated group health plans

\begin{tabular}{lcc}
\hline Observations & 112,937 & 43,598 \\
\hline R-squared & 0.22 & 0.531 \\
\hline Notes Stand
\end{tabular}

Notes: Standard errors in parentheses; ${ }^{*} p<0.10,{ }^{* *} p<0.05,{ }^{* *} p<0.01$. First column shows estimates of specification (1) from the text for soft-tissue conditions; second column shows result for traumatic injuries. 
Table 6: Estimated Effect of Workers' Compensation Reimbursement, Controlling for Group Health or Medicare Payments

\begin{tabular}{|c|c|c|c|c|}
\hline \multirow{2}{*}{$\begin{array}{l}\text { Medical } \\
\text { Condition }\end{array}$} & \multirow[b]{2}{*}{ Measures } & \multicolumn{3}{|c|}{ Specifications } \\
\hline & & WC Only & $\begin{array}{l}\text { WC and Group } \\
\text { Health }\end{array}$ & $\begin{array}{l}\text { WC and } \\
\text { Medicare }\end{array}$ \\
\hline & $\begin{array}{l}\text { Estimated coefficient of } \\
\text { reimbursement }\end{array}$ & $\begin{array}{l}0.0365^{\star \star \star} \\
(0.0054)\end{array}$ & $\begin{array}{l}0.0181^{\star \star \star} \\
(0.0056)\end{array}$ & $\begin{array}{l}0.0346^{\star \star \star} \\
(0.0054)\end{array}$ \\
\hline \multirow[t]{6}{*}{$\begin{array}{l}\text { Soft tissue } \\
\text { conditions }\end{array}$} & $\begin{array}{l}\% \text { of cases paid WC (vs. GH } \\
\text { payers) }\end{array}$ & $19.10 \%$ & $19.10 \%$ & $19.10 \%$ \\
\hline & $\begin{array}{l}\text { Estimated increase in the } \% \text { of } \\
\text { WC cases for st.dev increase in } \\
\text { revenues }\end{array}$ & $5.16 \%$ & $2.56 \%$ & $4.89 \%$ \\
\hline & $\begin{array}{l}\text { Estimated coefficient of } \mathrm{GH} \text { or } \\
\text { Medicare reimbursement }\end{array}$ & & $0.0768^{\star \star \star}$ & $0.3258^{\star \star \star}$ \\
\hline & & & $(0.0071)$ & $(0.0435)$ \\
\hline & Estimated coefficient of & -0.0037 & 0.0183 & -0.0035 \\
\hline & reimbursement & (0.0105) & $(0.0112)$ & $(0.0105)$ \\
\hline \multirow[t]{5}{*}{$\begin{array}{l}\text { Injury by } \\
\text { trauma }\end{array}$} & $\begin{array}{l}\% \text { of cases paid WC (vs. GH } \\
\text { payers) }\end{array}$ & $49.98 \%$ & $49.98 \%$ & $49.98 \%$ \\
\hline & $\begin{array}{l}\text { Estimated increase in the } \% \text { of } \\
\text { WC cases for st.dev increase in } \\
\text { revenues }\end{array}$ & $-0.21 \%$ & $1.03 \%$ & $-0.20 \%$ \\
\hline & $\begin{array}{l}\text { Estimated coefficient of } \mathrm{GH} \text { or } \\
\text { Medicare reimbursement }\end{array}$ & & $-0.0658^{\star \star \star}$ & -0.0919 \\
\hline & & & $(0.0117)$ & $(0.0849)$ \\
\hline & Observations & 129403 & 129371 & 129403 \\
\hline
\end{tabular}

Notes: Standard errors in parentheses; ${ }^{*} \mathrm{p}<0.10,{ }^{\star \star} \mathrm{p}<0.05,{ }^{\star \star \star} \mathrm{p}<0.01$. Top panel shows results for soft-tissue conditions; second panel for trauma injuries. First column shows estimates from specification (2) in the paper. Second column includes as an additional control group health reimbursement; third column includes as an additional control Medicare reimbursement. 
Table 7: Estimated Effect of Capitation and WC Fees for Multiple Specifications

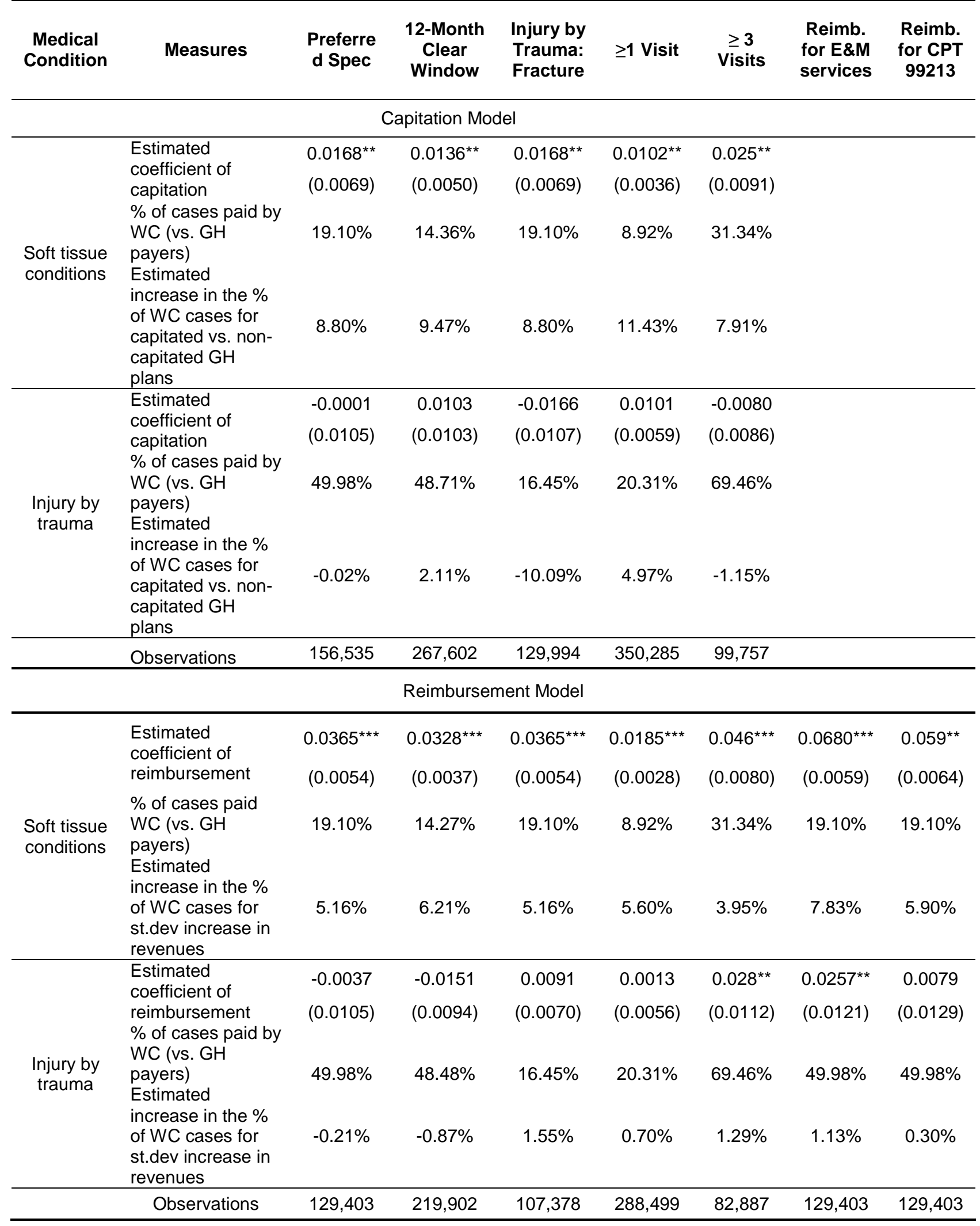


Notes: Standard errors in parentheses; ${ }^{*} \mathrm{p}<0.10,{ }^{*} \mathrm{p}<0.05,{ }^{* *} \mathrm{p}<0.01$ Top panel shows results for capitation model (equation 1) while second panel shows results for reimbursement model (equation 2). Within each of the two panels, top results are for soft-tissue conditions, and bottom for trauma injuries. First column shows baseline estimates from specifications (1) and (2) in the paper. Second column expands the window to exclude only those with no related injury and discontinuous coverage over the past 12 months (as opposed to 24 months used in the paper). Third column restricts trauma injuries just to fractures. Fourth column includes those with only one or more visit, while next column restricts to three or more (compared to base restriction of 2 or more). Fifth and sixth columns consider alternative reimbursement definitions discussed in text.

Table 8: Estimated Effect of Capitation for States with Different Percentages of Patients Covered by Capitated Group Health Plans

\begin{tabular}{|c|c|c|c|c|}
\hline \multirow{2}{*}{$\begin{array}{l}\text { Medical } \\
\text { Condition }\end{array}$} & \multirow[t]{2}{*}{ Measures } & \multicolumn{3}{|c|}{$\begin{array}{l}\% \text { of Patients Covered by Capitated Group Health } \\
\text { Plans }\end{array}$} \\
\hline & & $\geq 22 \%$ & $10 \%-21 \%$ & $<10 \%$ \\
\hline \multirow{3}{*}{$\begin{array}{l}\text { Soft tissue } \\
\text { conditions }\end{array}$} & $\begin{array}{l}\text { Estimated coefficient of } \\
\text { capitation }\end{array}$ & $\begin{array}{l}0.0484^{* \star *} \\
(0.0102)\end{array}$ & $\begin{array}{l}-0.0033 \\
(0.0088)\end{array}$ & $\begin{array}{l}-0.0018 \\
(0.0100)\end{array}$ \\
\hline & $\begin{array}{l}\% \text { of cases paid WC (vs. } \\
\text { GH payers) }\end{array}$ & $19.66 \%$ & $19.18 \%$ & $16.87 \%$ \\
\hline & $\begin{array}{l}\text { Estimated increase in the } \\
\% \text { of WC cases for } \\
\text { capitated vs. non- } \\
\text { capitated GH plans }\end{array}$ & $24.62 \%$ & $-1.72 \%$ & $-1.07 \%$ \\
\hline \multirow{4}{*}{ Injury by trauma } & $\begin{array}{l}\text { Estimated coefficient of } \\
\text { capitation }\end{array}$ & $\begin{array}{c}0.0303 \\
(0.0221)\end{array}$ & $\begin{array}{l}-0.0160 \\
(0.0173)\end{array}$ & $\begin{array}{l}-0.0462 \\
(0.0291)\end{array}$ \\
\hline & $\begin{array}{l}\% \text { of cases paid WC (vs. } \\
\text { GH payers) }\end{array}$ & $50.35 \%$ & $50.07 \%$ & $48.06 \%$ \\
\hline & $\begin{array}{l}\text { Estimated increase in the } \\
\% \text { of WC cases for } \\
\text { capitated vs. non- } \\
\text { capitated GH plans }\end{array}$ & $6.02 \%$ & $-3.20 \%$ & $-9.61 \%$ \\
\hline & Observations & 55,958 & 84,202 & 16,302 \\
\hline
\end{tabular}

Notes: Standard errors in parentheses; ${ }^{\star} p<0.10,{ }^{\star \star} p<0.05,{ }^{\star \star \star} p<0.01$. Top panel shows results for soft-tissue conditions; second panel for trauma injuries. Each column shows results from specification (1) in the paper, but the sample is divided into states where more than $22 \%, 10-21 \%$ and less than $10 \%$ of those insured are enrolled in capitated plans. 